\title{
IBM PEMASARAN PRODUK KERAJINAN HASIL DAUR ULANG SAMPAH RUMAH TANGGA BERBASIS WEB
}

\section{$I_{B} M$ MARKETING OF HANDICRAFT PRODUCTS RESULTS WEB-BASED WASTE HOUSEHOLD WASTE}

\author{
Rusham $^{1 a}$ dan J Pramono ${ }^{1}$ \\ 1FE-Manajemen, Universitas Islam “45” Bekasi, Indonesia \\ a Korespondensi: Rusham, Email: rushamsangaji@gmail.com \\ (Diterima: 28-11-2017; Ditelaah: 29-11-2017; Disetujui: 15-03-2018)
}

\begin{abstract}
The community empowerment program in the form of the use of household waste into a creative handicraft industry is increasingly being actively developed by various regions in Indonesia, this program also develops in Bahagia Sub-district, Babelan District, Bekasi Regency, in this region itself there is a small group called POSDAYA BAHAGIA where POSDAYA members and administrators are housewives. POSDAYA, managed by housewives, is able to recycle household waste into compost and handicrafts in the form of bags, wallets and others. The main problem faced by POSDAYA's mothers is the marketing of products, one of the efforts to be developed is to market these handicraft products through the website as a promotional effort, while the promotion is still using traditional patterns. The theme of IbM Marketing handicraft products from recycled web-based household waste. The decision to take this theme begins with the results of social surveys and interactions with POSDAYA Management and residents who make activities in making handicrafts from the results of recycling in Bahagi Village. Web-based product marketing and training is carried out by training POSDAYA groups who will manage and market the recycled products through the Pasar Bahagia Online Website with an integrated service system. The output produced by this IbM program is the skill of partners to produce cooperative products from the results of recycling of household waste and marketing service systems through the Bahagia Website and the formation of productive economic businesses managed jointly.
\end{abstract}

Keywords: garbage, craft products, web-based marketing.

\begin{abstract}
ABSTRAK
Program pemberdayaan masyarakat berupa pemanfaatan sampah rumah tangga menjadi industri kerajinan tangan yang kreatif semakin giat dikembangkan oleh berbagai daerah di Indonesia, program ini juga berkembangan di Kelurahan Bahagia Kecamatan Babelan Kabupaten Bekasi, di wilayah ini sendiri terdapat kelompok kecil (small group) yang bernama POSDAYA BAHAGIA dimana anggota dan pengurus POSDAYA tersebut adalah Ibuibu rumah tangga. POSDAYA yang dikelola oleh ibu-ibu rumah tangga tersebut mampu mendaur ulang sampah rumah tangga menjadi pupuk kompos dan kerajinan tangan berupa tas, dompet dan lain-lain. Persoalan utama yang dihadapi oleh kelompok ibu-ibu POSDAYA ini adalah pada pemasaran hasil produk, salah satu upaya yang ingin dikembangkan adalah memasarkan produk kerajinan ini melalui website sebagai upaya promosi, yang sementara ini promosi yang dilakukan masih menggunakan pola-pola tradisional. Tema IbM Pemasaran produk kerajinan tangan dari hasil daur ulang sampah rumah tangga berbasis web. Keputusan mengambil tema ini diawali dari hasil survey dan interaksi sosial dengan Pengurus POSDAYA maupun warga yang melakukan aktivitas membuat kerajinan tangan
\end{abstract}


dari hasil daur ulang sampah yang berada di Kelurahan Bahagi.Pembuatan web dan Pelatihan pemasaran produk berbasis Web dilakukan dengan melatih kelompok POSDAYA yang akan mengelola dan memasarkan produk hasil daur ulang sampah tersebut melalui Website Pasar Bahagia Online dengan sistem layanan yang yang terintegrasi. Luaran yang dihasilkan oleh program IbM ini adalah keterampilan mitra untuk memproduksi produk kerjainan dari hasil daur ulang sampah rumah tangga dan sistem layanan pemasaran melalui Website Bahagia serta terbentuknya usaha ekonomi produktif yang dikelola secara bersama.

Kata kunci: Sampah, produk kerajinan, pemasaran berbasis web.

Rusham \& Pramono, J. (2018). IbM Pemasaran Produk Kerajinan Hasil Daur Ulang Sampah Rumah Tangga Berbasis Web. Qardhul Hasan: Media Pengabdian kepada Masyarakat 4(1): 31-40.

\section{PENDAHULUAN}

Kelurahan Bahagia yang berada di Kecamatan Babelan Kabupaten Bekasi memiliki luas wilayah sekitar 18 Ha dengan jumlah penduduk berdasarkan data kependudukan tahun 2015 adalah berjumlah 76.420 jiwa, terdri dari 39.032 jiwa laki-laki dan 37.388 jiwa perempuan, terdiri dari 19.074 Kepala Keluarga (KK) meliputi 47 Rukun Warga (RW) dan 379 Rukun Tetangga (RT) serta ada sekitar 16 Pos Pemberdayaan Keluarga (POSDAYA). Kelompok pemberdayaan masyarakat yang disebut dengan POSDAYA, dimana pengurus dan anggotanya merupakan ibu-ibu rumah tangga yang menjadi kader utama. Salah satu aktivitas dari POSDAYA adalah pengelolaan lingkungan yaitu pemanfaatan sampah rumah tangga berupa sampah organik menjadi kompos dan sampah unorganik menjadi produk kerajinan seperti tas, dompet, taplak meja, bunga hias dan lain-lain.

Untuk mengatasi pertumbuhan dan penyebaran sampah plastik yang relatif masif, maka berbagai cara dilakukan supaya sampah plastik ini dapat dimanfaatkan menjadi produk bernilai ekonomi. Langkah tersebut antara lain memanfaatkan sampah plastik sebagai bahan baku pembuatan berbagai produk kerajinan tangan. Pemanfaatan sampah plastik sudah banyak dilakukan oleh kelompok usaha kerajinan di berbagai daerah, bahwa hasil kerajinan tangan berbahan plastik di Kelurahan bahagia Kecamatan Babelan Kaupaten Bekasi ini merupakan salah satu dari bagian yang harus mendapatkan perhatian yang serius. Produk kerajinan tangan yang dihasilkan diantaranya tas, wadah tisu, tempat pensil, sandal, kipas tangan, wadah hantaran, taplak meja, bunga-bunga hias dan beragam souvenir-souvenir.

POSDAYA Bahagia ini berlokasi di Kelurahan Bahagia Kecamatan Babelan dan berada di Komplek Pondok Ungu Permai, Posdaya ini semua di isi oleh kelompok ibuibu sebagai kadernya. Salah satu kegiatan Posdaya ini adalah mengembangkan Bank Sampah dan Lingkungan bersih serta memanfaatkan sampah ssebagai bahan baku kerjainan tangan yang bernilai ekonomis. Disamping kegiatan ini ekonomi, kelompok ini juga mengembangkan program pendidikan PAUD, mobil pintar dan lingkungan.

Melihat potensi yang dimiliki mitra ini, maka upaya pengembangan yang sudah dilakukan melalui program pemgandian kepada masyarakat yang dilakukan Tim Fakultas Ekonomi UNISMA Bekasi melakukan pendampingan, maupun pemberdayaan masyarakat pada umumnya. Dari hasil program PPM yang dilaksanakan oleh Fakultas Ekonomi Unisma Bekasi sejak tahun 2010, maka ada beberapa hal penting yang harus dikembangkan:

1. Kelompok POSDAYA ini dapat diarahkan menjadi usaha ekonomi produktif masyarakat. 
2. Potensi yang ada saat ini dapat dikembangkan menjadi usaha ekonomi produksi, bila produknya memiliki standar yang memadai, memiliki potensi pasar, dan adanya dukungan yang kuat dari pemerintah Kelurahan Bahagia maupun stakeholder lainnya.

3. Dari berbagai produk kerajinan mereka yang sudah ada dan berbahan bahan baku dari limbah/sampah rumah tangga harus mendapatkan sentuhan inovasi di bidang produksi dan pemasarannya, sehingga nanti mampu memberikan dampak secara ekonomi bagi keluarga.

\section{MATERI DAN METODE}

\section{Permasalahan Mitra}

Dari analisis situasi di atas diketahui bahwa permasalahan mitra adalah sebagai berikut.

1. Kualitas keterampilan dalam mengelola sampah daur ulang yang masih rendah

a. Kurangnya pembinaan yang diterima oleh ibu-ibu rumah tangga dalam mengembangkan keterampilan / kreativitas dalam mengelola sampah daur ulang

b. Minimnya kesadaran dari sebagian besar masyarakat dalam mengelola dan memanfaat sampah rumah tangga yang didaur ulang menjadi sebuah produk yang memilki nilai jual

c. Melimpahnya sampah rumah tangga dari plastik di kelurahan Bahagia yang tidak dimanfaatkan sehingga berimbas pada kebersihan dan kelestarian lingkungan sekitar.

2. Produk yang dihasilkan belum mampu dipasarkan

Produk kerajinan dari hasil daur ulang sampah yang dihasilkan belum dipasarkan secara konvensional maupun dipasarkan secara online berbasis WEBSITE, saat ini hanya dipasarkan antar tetangga saja, oleh karena itu motivasi produksinya akan menurun.
3. Pengelolaan manajemen usaha yang masih rendah

Selain kurang dalam keterampilan mengelola sampah, mereka pun kurang memahami bagaimana konsep manajemen usaha, baik dalam pengelolaan produksi, pemasaran, dan pembukuan hasil usaha juga belum sama sekali dilakukan. Oleh karena itu, masih banyak warga yang tidak mengetahui kalau ternyata di Kelurahan Bahagia ada hasil karya kreatif dari pemanfaatan sampah rumah tangga yang diciptakan oleh ibu-ibu rumah tangga.

4. Pemilihan strategi marketing yang belum tepat

Mitra mengalami kesulitan dalam memasarkan produk hasil daur ulang sampah rumah tangga juga menjadi permasalahan umum yang dihadapi kelompok POSDAYA tersebut, karena ketika produk sudah dihasilkan, pertanyaan yang timbul dalam pemikiran mereka adalah, bagaimana dan kemana produk tersebut untuk dipasarkan. Selama ini pemasaran/penjualan produk mereka hanya melalui bazzar dan personal selling pada lingkup wilayah yang sangat terbatas. Oleh karena itu untuk dapat mengembangkan pemasaran yang efektif perlu pemasaran berbasis Web agar pemasaran produk antara POSDAYA yang satu dengan POSDAYA yang lain dapat terintegrasi dengan baik dan informasi mengenai produk hasil daur ulang sampah dapat dengan cepat diakses oleh masyarakat dimanapun mereka berada.

5. Mitra belum memiliki ketrampilan dalam mengembangkan dan memsarkan produk hasil usaha melalui pemasaran yang bersifat konvensional maupun online.

6. Mitra belum memiliki ketrampilan dalam mengelola mutu produk secara sustainable.

7. Belum ada keterlibatan pemerintah Daerah dalam memberikan bantuan bimbingan teknis kepada mitra dalam 
meningkatkan produksi kerajinan dari hasil daur ulang.

\section{Target Luaran}

1. Mitra memiliki ketrampilan dalam memproduksi produk kerajinan dari hasil daur ulang sampah yang ada disekitar lingkungannya yang sudah dikembangkan melalui bank sampah.

2. Mitra memiliki keterampilan mengelola dan mengembangkan pemasaran produk hasil daur ulang sampah secara online.

3. Mitra dapat meingkatkan volume penjualan produk kerajinannya, sehingga berdampak pada peningkatan pendapatan mitra.

4. Peningkatan pemahaman mitra mengenai penggunaan Domain/Website Pasar Bahagia Online beserta perangkatnya yang berfungsi sebagai alat promosi penjualan produk.

5. Sistem pelayanan pemasaran produk yang terpadu antar POSDAYA.

6. Mitra memiliki jaringan yang luas dalam memasarkan produk kerajinannya baik secara online dengan menggunakan website yang sudah dibangun, maupun secara konvensional dengan memanfaatkan jaringan kelembagaan POSDAYA yang sudah terbangun.

7. Mitra dapat merintis dan mengembangkan usaha yang sekarang hanya dikelola secara tradisional perorangan menjadi usaha ekonomi mikro produktif, terutama dalam hal pemasaran hasilnya, maka dengan adanya program ini mitra dapat meningkatkan pemasaran hasilnya melalui kelembagaan usaha yang lebih konvensional dan aplikatif.

8. Terbangun jaringan kerjasama yang baik antar POSDAYA dengan menggunakan jaringan web sebagai media untuk melakukan pemasaran hasil produk kerajinannya.

Jadi berdasarkan beberapa poin yang menjadi target luaran program IbM seperti yang disebutkan di atas, kalau mitra sudah dapat memasarkan produknya dengan baik melalui website, maka mitra bisa juga dikembangkan sebagai usaha plasma yang dikembangkan untuk menjadi UMKM, dan setiap plasma usaha membentuk jaringan pengumpulan bahan baku mulai tingkat rumah tangga-RW-Kelurahan sampai pada pengolahan. Kemudian pasar hasil pengolahan plastik dikembangkan melalui website juga melalui penyerapan secara luas, khususnya untuk pengolahan biji plastik, sampai industri cetakan plastik (alat rumah tangga), disamping produk-produk kerajinan yang sudah dihasilkan sekarang.

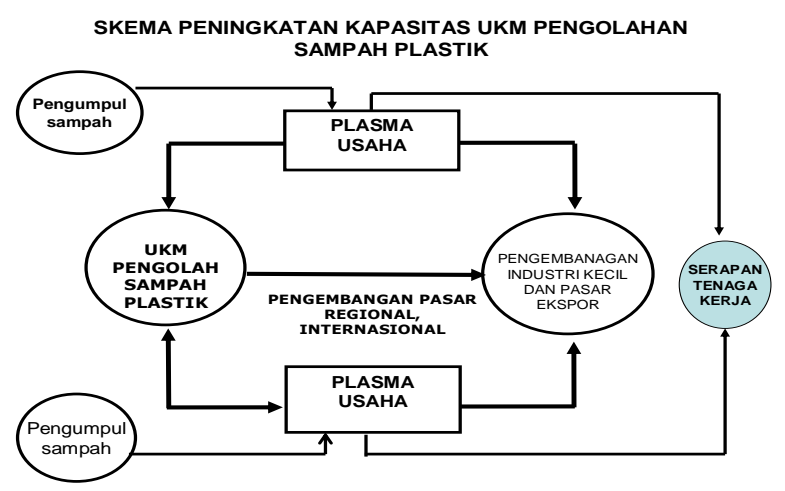

Gambar 1 Skema umum pengelolaa sampah plastik

\section{Metode}

\section{Metode Pendekatan Kepada Mitra}

1. Urun rembug : pertemuan bernuansa kekeluargaan untuk memahami secara rinci kondisi, kebutuhan dan pola komunikasi mitra.

2. Diskusi terarah dan Sosialisasai (Focused Group Discussion - FGD): untuk memberikan pemahaman kepada mitra tentang orientasi solusi yang akan diberikan mengenai upaya peningkatan produksi dan pemasaran hasil produk kerjanan tangan melalui website.

3. Mempersiapkan aplikasi WEBSITE : Sosialisasi tentang Manfaat WEBSITE untuk pemasaran produk hasil kerajinan

4. Pelatihan : kegiatan pembelajaran untuk meningkatkan keterampilan dan kreatifitas dalam mengembangkan produk hasil daur ulang sampah rumah tangga, melatih penggunaan website 
yang digunakan melalui pemasaran berbasis Aplikasi dan pengelolaan Web (Teori : Praktek=40:60).

5. Pengorganisasian melalui (Pendirian Pasar Bahagia Online adalah Pengintegrasian pemasaran produk hasil daur ulang sampah berbasis web) : upaya penataan pemasaran terpadu antar POSDAYA melalui website dimana domain website tersebut akan dikelola oleh operator yang ditunjuk oleh kelompok POSDAYA/Ibu-ibu rumah tangga tersebut.

6. Memberikan Pendampingan Program, melalui Pendampingan dan uji coba aplikasi dalam kurun waktu pelaksanaan kurang lebih 6 bulan sesuai dengan jangka waktu program IbM, mempersiapkan juklak dan juknis penggunaan Website online pemasaran, melatih kader utama sebagai operator pelaksana, selain anggota yang lainnya, memberikan pengetahuan cara mendesain produk yang ditawarkan melalui website.

7. Penyiapan mitra menjadi Usaha Ekonomi Produktif, melalui proses pendampingan ini dilakukan juga pelatihan dalam rangka mempersiapkan mitra untuk menjadi pelaku ekonomi produktif yang mandiri dan berada dalam kelembagaan POSDAYA yang dikelola secara bersama, memberikan pelatihan manajemen usaha ekonomi produktif, antara lain kelembagaan usaha, pengelolaan keuangan usaha bersama, pemasaran hasil usaha berbasis web.

\section{Mendesain Prosedur dan Tahapan Kerja}

Prosedur dan tahapan kerja yang digunakan dalam program ini seperti tergambar pada Gambar 2 dan Gambar 3.

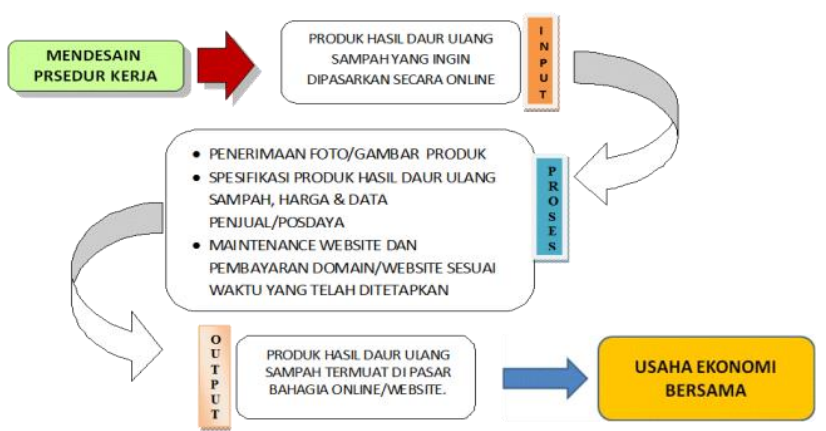

Gambar 2 Prosedur kerja

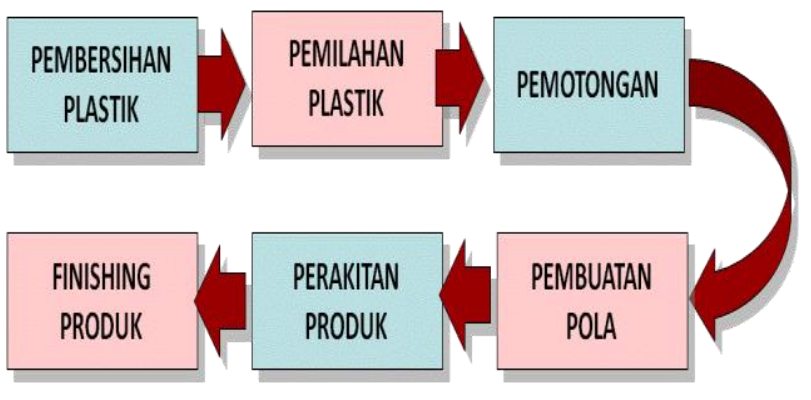

Gambar 3 Tahapan kerja

\section{HASIL DAN PEMBAHASAN}

\section{Kegiatan IbM}

Kegiatan IbM ini terdiri dari tahapan sebagai berikut.

1. Persiapan kegiatan berupa survey dan kunjungan pendahuluan ke POSDAYA. Persiapan meliputi: (a) Melakukan komunikasi awal tentang rencana kegiatan antara Tim Pelaksana dengan kedua kedua Mitra IbM, (b) Diskusi rencana pelaksanaan IbM antara Tim Pelaksana dengan kedua kedua Mitra IbM, (c) Menentukan jadwal pelaksanaan kegiatan yang telah disepakati bersama antara Tim Pelaksana dengan kedua Mitra IbM, (d) Menentukan dan mendiskusikan jenis partisipasi mitra untuk mendukung setiap kegiatan yang diusulkan oleh Tim Pelaksana IbM.

2. Pelaksanaan kegiatan lapangan IbM meliputi: (a) Peningkatan kualitas, efisiensi tenaga, dan waktu pelaksanaan kegiatan (b) Peningkatan kemampuan desain (rancang bangun) dan pemutakhiran (update) informasi produk 
melalui website. Gambaran pelaksanaan kegiatan dapat dilihat pada Gambar 4.

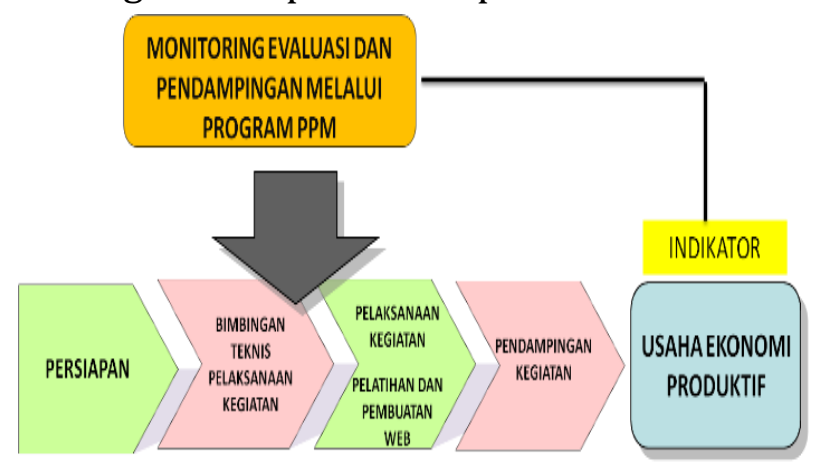

Gambar 4 Proses pelaksaanaan kegiatan

Selain menyusun prosedur, tahapan dan proses pelaksanaan kerja, perlu juga mendesain website POSDAYA sebagai cikal bakal pasar online yang dirancang seperti gambar 5.
Sementara proses pelaksanaan pekerjaan program IbM seperti tabel 1, mulai dari persiapan sampai dengan pendampingan dan monitoring.

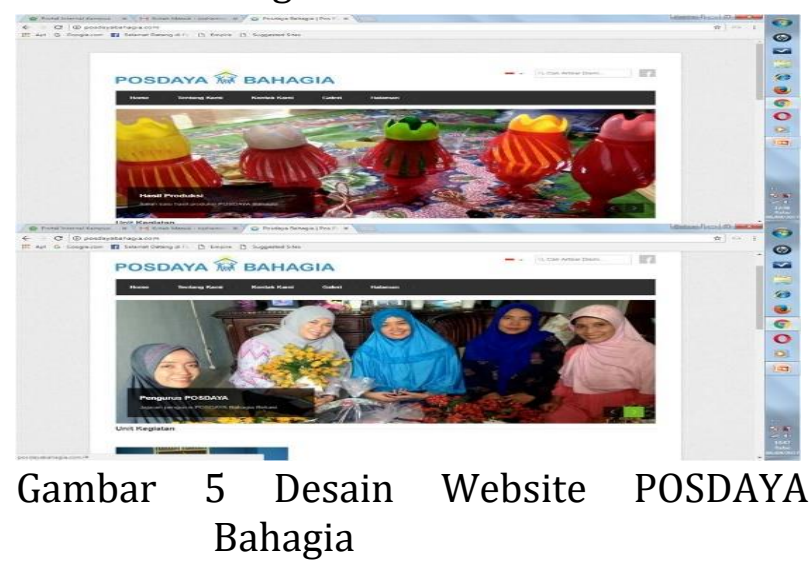

Tabel 1 Hasil Pelaksanaan Program IbM di Kelurahan Bahagia

\begin{tabular}{|c|c|c|}
\hline No & Kegiatan & Pelaksana \\
\hline \multirow[t]{7}{*}{ A } & Persiapan & Pelaksana dan \\
\hline & 1. Persiapan pelaksanaan Kegiatan, antara lain melakukan & Mitra \\
\hline & $\begin{array}{l}\text { 2. Melakukan diskusi dengan mitra terkait program yang akan di } \\
\text { laksanakan }\end{array}$ & \\
\hline & 3. Diskusi tentang Partisipasi Mitra & \\
\hline & $\begin{array}{l}\text { 4. Menyusun rencana kegiatan pelatihan, dilaksanakan pada } \\
\text { tanggal 3-5 Juni } 2017 \text {. }\end{array}$ & \\
\hline & $\begin{array}{l}\text { 5. Pengadaan alat dan bahan berupa seperangkat komputer dan } \\
\text { website, dilaksanakan pada tanggal 14-16 Juni } 2017\end{array}$ & \\
\hline & 6. Menentukan jadwal pelaksanaan kegiatan & \\
\hline
\end{tabular}

\begin{tabular}{|c|c|c|}
\hline No & Kegiatan & Pelaksana \\
\hline \multirow[t]{8}{*}{ B } & Pelaksanaan Kegiatan & Pelaksana \\
\hline & 1. Kunjungan ke Lokasi Mitra & Mitra \\
\hline & $\begin{array}{l}\text { 2. Persiapan kebutuhan pendukung bagi kegiatan pelatihan, } \\
\text { praktek, dan pendampinganDiskusi tentang Partisipasi Mitra }\end{array}$ & \\
\hline & $\begin{array}{l}\text { 3. Persiapan juga dilakukan terhadap bahan-bahan dan alat yang } \\
\text { dipakai pada pelatihan }\end{array}$ & \\
\hline & $\begin{array}{l}\text { 4. Pengadaan alat dan bahan berupa seperangkat komputer dan } \\
\text { website, dilaksanakan pada tanggal 14-16 Juni } 2017\end{array}$ & \\
\hline & $\begin{array}{l}\text { 5. Sosialisasi dan Implementasi kegiatan program IbM hari } \\
\text { pertama }\end{array}$ & \\
\hline & 6. Pelatihan WEB & \\
\hline & 7. Pelatihan peningkatan kapasitas SDM Mitra & \\
\hline
\end{tabular}




\begin{tabular}{|c|c|c|}
\hline No & Kegiatan & Pelaksana \\
\hline $\mathrm{C}$ & $\begin{array}{l}\text { Pelaksanaan Kegiatan Lanjutan } \\
\text { 1. Penyelesaian Desain website rumah online produk agar } \\
\text { menjadi selesai } 100 \% \text {. } \\
\text { 2. Pelatihan pemasaran produk secara online melalui website } \\
\text { melalui sistem layanan terpadu online shop } \\
\text { 3. Pelatihan peningkatan ketrampilan dalam pembuatan produk } \\
\text { 4. Uji coba Website dan pendampingan } \\
\text { 5. Mempersiapkan kelembagaan usaha ekonomi produktif } \\
\text { POSDAYA }\end{array}$ & $\begin{array}{l}\text { Pelaksana dan } \\
\text { Mitra }\end{array}$ \\
\hline No & Kegiatan & Pelaksana \\
\hline $\mathrm{D}$ & $\begin{array}{l}\text { Monitoring dan Pendampinga Kegiatan Lanjutan } \\
\text { 1. Monitoring tahap pertama sampai dengan selesainya program } \\
\text { IbM } \\
\text { 2. Pembuatan Laporan Kemajuan dan Laporan Akhir } \\
\text { 3. Unggah Laporan ke simlitabmas } \\
\text { 4. Peresmian Pasar ONLINE yang melibatkan seluruh POSDAYA, } \\
\text { Kelurahan Bahagia, Tokoh Masyarakat dan Pemerintah } \\
\text { Kabupaten Bekasi, akan dilaksanakan pada bulan Oktober } \\
2017 \\
\text { 5. Pendampingan Prgoram sampai dengan bulan Desember } \\
\text { melalui program PPM }\end{array}$ & $\begin{array}{l}\text { Pelaksana dan } \\
\text { Mitra }\end{array}$ \\
\hline
\end{tabular}

Berdasarkan uraian pelaksanaan kegiatan tersebut di atas, maka berikut ini adalah output yang di hasilkan oleh

Tabel 2 Rekapitulasi output program IbM, dan diukur dengan indikator adanya perbedaan kondisi mitra sebelum dan sesudah adanya program ini.

\begin{tabular}{|c|c|c|}
\hline No & $\begin{array}{l}\text { Kondisi Sebelum Program } \\
\text { Ibm }\end{array}$ & Kondisi Sesudah Program Ibm \\
\hline 1 & $\begin{array}{l}\text { Kelembagaan dan struktur } \\
\text { Bank Sampah yang belum } \\
\text { memadai }\end{array}$ & $\begin{array}{l}\text { - Sudah ada kelembagaan Bank Sampah } \\
\text { - Aktivitas penimbangan Bank sampah terjadwal (setiap } \\
\text { hari sabtu dan minggu) } \\
\text { - Pengelolaan Bank Sampah oleh POSDAYA dilakukan } \\
\text { secara bersama }\end{array}$ \\
\hline 2 & $\begin{array}{l}\text { Posdaya belum } \\
\text { terintegrasi }\end{array}$ & $\begin{array}{l}\text { - Terbentuk kader utama dari masing-masing POSDAYA } \\
\text { - } 16 \text { POSDAYA yang ada terintegrasi dan dikoordinasi } \\
\text { oleh POSDAYA Induk pada tingkat Kelurahan Bahagia } \\
\text { - Semua kegiatan Posdaya terkoordinasi dengan baik } \\
\text { - Semua produk posdaya dipasarkan secara bersama } \\
\text { melalui POSDAYA Induk dengan menggunakan Web }\end{array}$ \\
\hline 3 & $\begin{array}{l}\text { Sampah plastik belum } \\
\text { termanfaatkan dengan } \\
\text { baik }\end{array}$ & $\begin{array}{l}\text { - Terbentuk kader pada masing-masing POSDAYA } \\
\text { - Terbangun kesadaran bersama untuk memanfaatkan } \\
\text { sampah plastik sebagai produk yang bernilai ekonomis } \\
\text { - Semua POSDAYA memanfaatkan sampah plastik untuk } \\
\text { membuat berbagai macam Produk (fas bunga, taplak } \\
\text { meja, tas, tempat tisu, lampu hias dan produk-produk }\end{array}$ \\
\hline
\end{tabular}




\begin{tabular}{|c|c|c|}
\hline & & $\begin{array}{l}\text { kerajinan lainnya } \\
\text { - Produk yang dihasilkan dijual pada lingkungan sekitar } \\
\text { baik di tingkat kelurahan maupun tingkat kecamatan } \\
\text { (baik secara offline maupun online) }\end{array}$ \\
\hline 4 & Belum ada produk & $\begin{array}{l}\text { - Saat ini sudaha banyak variasi produk yang dihasilkan } \\
\text { setelah mendapatkan pelatihan } \\
\text { - Produk yang dihasilkan antara lain fas bunga, taplak } \\
\text { meja, tas, tempat tisu, lampu hias dan produk-produk } \\
\text { kerajinan lainnya } \\
\text { - Masing-masing POSDAYA dan anggota masyarakat } \\
\text { lainnya yang tergabung mendapatkan penghasilan } \\
\text { (yaitu dari sampah yang ditimbang dan produk yang } \\
\text { dijual } \\
\text { - Rata-rata per POSDAYA mendapatkan penghasilan } \\
\text { antara Rp. } 1.2 \text { juta sampai dengan } 2 \text { juta perminggu) }\end{array}$ \\
\hline 5 & $\begin{array}{l}\text { Mitra belum menggunakan } \\
\text { media online (web) untuk } \\
\text { media promosi }\end{array}$ & $\begin{array}{l}\text { - Masing-masing mitra POSDAYA dapat mengakses } \\
\text { Website sebagai media promosi porduk } \\
\text { - Masing-masing POSDAYA memiliki admin yang akan } \\
\text { update informasi produk dan lain sebagainya } \\
\text { - Mitra bisa link dengan PEMDA Kabupaten Bekasi, } \\
\text { YDSM, dan instansi lain sebagai mitra } \\
\text { - Saat ini POSDAYA memiliki } 3 \text { unit komputer yang } \\
\text { online }\end{array}$ \\
\hline 6 & $\begin{array}{l}\text { Mitra belum mendapatkan } \\
\text { pelatihan dan } \\
\text { pendampingan }\end{array}$ & $\begin{array}{l}\text { - Mitra sudah mendapatkan Pelatihan Pemsaran, } \\
\text { pelatihan pembuatan produk, pelatihan penggunaan } \\
\text { website, pelatihan manajemen usaha ekonomi } \\
\text { produktif } \\
\text { - Mitra akan mendapatkan pendampingan } \\
\text { - Mitra juga sudah menjadi kelompok binaan/wilayah } \\
\text { binaan resmi dari Fakultas Ekonomi UNISMA Bekasi, } \\
\text { dan setiap tahun program PPM Fakultas Ekonomi di } \\
\text { programkan pada mitra POSDAYA } \\
\text { - Mitra mendapatkan pendampingan secara } \\
\text { berkelanjutan }\end{array}$ \\
\hline 7 & $\begin{array}{l}\text { Belum terbentuk } \\
\text { kelompok usaha ekonomi } \\
\text { produktif }\end{array}$ & $\begin{array}{l}\text { - Saat ini sudah dirintis Usaha Ekonomi Produktif yang } \\
\text { dikelola oleh POSDAYA Induk } \\
\text { - Bila program perintisan usaha ekonomi produktif } \\
\text { berhasil, maka tahun kedua melalui program PPM FE } \\
\text { UNISMA BEKASI akan dibentuk Badan usaha bersama } \\
\text { semacam BUMDES yang berbadan hukum }\end{array}$ \\
\hline
\end{tabular}

Dalam menjaga keberlanjutan program, salah satu kegiatan yang dilakukan adalah monitoring dan evaluasi yang bersifat komprehensif. Gambar 6 adalah polas monitoring yang dilakukan, agar programprogram yang sudah dibangun dapat dijaga keberlanjutannya. Sementara untuk mengembangkan program IbM ini menjadi usaha ekonomi produktif dan menjadikan POSDAYA sebagai mitra ataupun kelompok binaan yang berkelanjutan, maka pola yang sudah dilaksanakan dapat dilihat pada Gambar 7. 


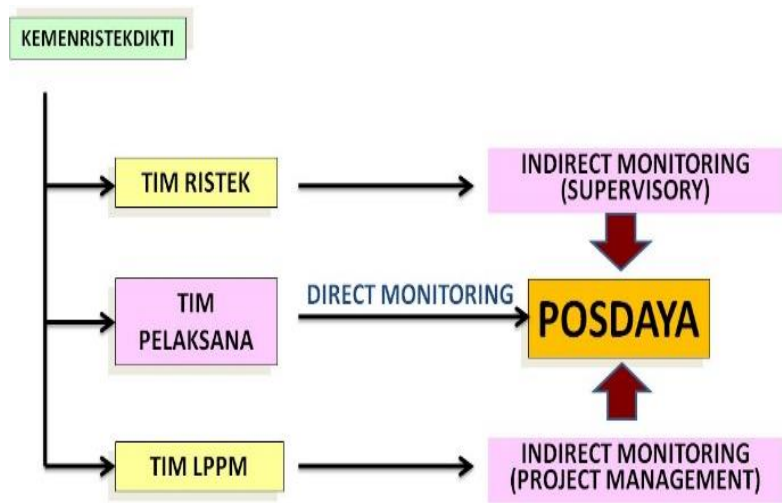

Gambar 6 Proses pelaksaanaan monitorng kegiatan

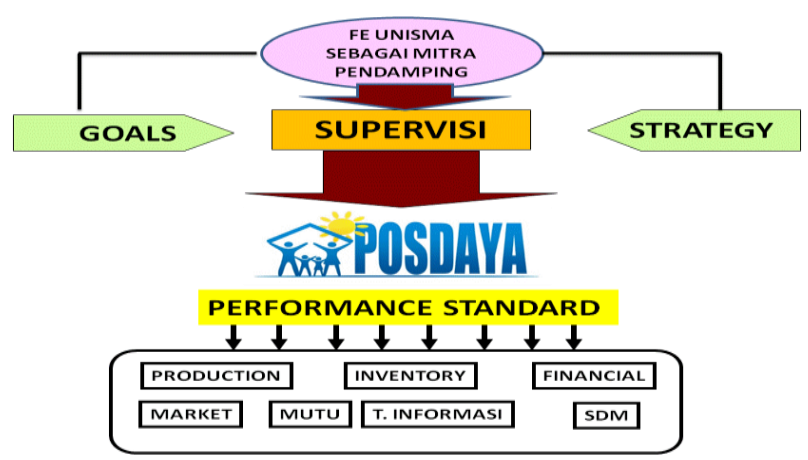

Gambar 7 POSDAYA sebagai kelompok binaan

\section{KESIMPULAN DAN IMPLIKASI}

1. Ketrampilkan anggota posdaya bahagia dan flamboyan dalam membuat kerajinan tangan berupa tas, taplak meja, fash bunga dan lain-lain yang bahan bahan bakunya dari sampah plastik sangat memberikan peluang usaha bagi warga sekitar.

2. Dengan dikembangkan konsep pemasaran melalui Website, maka potensi produk yang dihasilkan oleh kedua posdaya diharapkan terpasarkan dengan baik

3. Salah satu potensi yang sudah dikembangkan melalui program IbM ini adalah produk kerajinan yang dapat dimanfaatkan secara ekonomis oleh seluruh anggota POSDAYA, maka setelah dilakukan pembinaan, pelatihan dan pendampingan yang berkelanjutan, maka POSDAYA dapat mengembangkan pemasaran produk ini melalui website.
4. Perwujudan peran pemberdayaan masyarakat melalui program pengabdian, tidak hanya mensyaratkan dana dan ketrampilan yang memadai dan tepat guna, tapi juga sangat dibutuhkan dan bahkan sangat penting, yakni kemampuan memahami kebutuhan masyarakat secara akurat dan representatif.

Untuk mencapai hasil yang terbaik dengan manfaat seluas-luasnya bagi mitra melalui program IbM ini, maka perlu diperhatikan hal-hal sebagai berikut.

1. Perlu jalinan komunikasi dengan masyarakat termasuk membuka ruang interaksi melalui mediasi para tokok masyarakat sangat penting untuk dilakukan sejak dini agar kondisi dapat dipahami secara akurat, proporsional dan apa adanya untuk mengembangkan program secara berkelanjutan.

2. Kesinambungan komunikasi antara pelaku pengabdian dengan mitra dan pemerintah setempat perlu dipelihara agar perkembangan yang sangat dinamis di tengah-tengah warga masyarakat yang dimaksud dapat direkam setiap saat dan diakomodasi sesuai target yang direncanakan.

3. Pengabdian yang berkelanjutan sangat dibutuhkan, sehingga pembimbingan dan pengawalan pertumbuhan kualitas masyarakat dapat terwujud secara signifikan. Karena itu program PPM melalui IbM ini sebaiknya difokuskan pada orientasi pertumbuhan masyarakat yang dirancang melalui road map kegiatan yang berkala, terpadu, menyeluruh dan berkesinambungan.

\section{DAFTAR PUSTAKA}

Al Fatta, Hanif. 2007. Analisis dan Perancangan Sistem Informasi untuk KeunggulanBersaing Perusahaan dan Organisasi Modern. Yogyakarta

Andi Jogiyanto, H.M. 2005. Analisis \& Desain Sistem Informasi: pendekatan terstruktur 
teori dan praktek aplikasi bisnis. Yogyakarta

Andi Suyanto, M. 2003. Strategi Periklanan pada E-Commerce Perusahaan Top Dunia. Yogyakarta

Alfiandra. 2009. Kajian partisipasi masyarakat yang melakukan pengelolaan persampahan 3R di Kelurahan Ngaliyan dan Kalipancur Kota Semarang [tesis]. Semarang (ID): Universitas Diponegoro. [Internet]. [diunduh 2013 November 9]. Tersedia pada: http://eprints.undip.ac.id/24266/1/ALFI ANDRA.pdf.

Budiman RA, Saam Z, Thamrin. 2013. Partisipasi dan persepsi masyarakat dalam upaya menjaga mengelola lingkungan hidup dan mempertahankan predikat kota bersih. Jurnal Ilmu Lingkungan [Internet]. [diunduh 2013 Oktober 9]. 7(2):103-113. Tersedia pada: http://ejournal.unri.ac.id/index.php/JIL/ article/download/1498/ 1473.

Candra I. 2012. Partisipasi masyarakat dalam pengelolaan sampah rumah tangga (Studi kasus di Kelurahan Siantan Tengah Kecamatan Pontianak Utara). SociodevJurnal Ilmu Sosiatri [internet]. [diunduh 2013 oktober 9]; 1(1):1-21. Tersedia pada: http:// jurnalmahasiswa. fisip.untan.ac.id/index.php/jurnalsosiatri/a rticle/view/140.

DP2M Dikti. (2006). Panduan Pengelolaan Program Hibah DP2M Ditjen Dikti. Jakarta: DP2M Ditjen Dikti.

DP2M Dikti. (2009). Buku Panduan Pengelolaan Hibah Program Pengabdian Kepada Masyarakat DP2M Ditjen Dikti Depdiknas. Jakarta: DP2M Ditjen Dikti

Lana, Sularto, (2007) Pengaruh Informasi Periklanan Di internet dan Pemasaran Melalui Email Terhadap Pemrosesan Informasi Periklanan Serta Implikasinya Terhadap Keputusan Pembelian Produk Di Wilayah Jabodetabek, Disertasi Doktor, Imu Ekonomi Universitas Gunadarma. Jakarta.

LPPM Unisma, 2012. Laporan Pelaksanaan KKN Unisma Bekasi di Kelurahan Bahagia

Kalakota Dan Whinston, (1996) Frontiers Of Electronic Commerce, Addison-Wesley Publilshing Company, Inc, Massachusetts.

Purbo, W.Onno, 2003. Membangun Server Internet dengan FreeBSD, Jakarta, PT Elex Media Komputindo Simamora, Bilson.

Oetomo, Budi Sutedjo Dharma. (2001). "Perspektif e-Business: Tinjauan Teknis, Manajerial, dan Strategi", Penerbit Andi Yogyakarta. 